\section{AGRICULTURE AND RITUAL LANDSCAPE: A CASE STUDY FROM THE MAGARS OF ARGAL, BAGLUNG DISTRICT, NEPAL}

Man Bahadur Khattri*

\subsection{Introduction}

The signification of rituals and landscape in human socio-cultural life is very important. We must not try to undermine them looking just as traditions. We must try to see social, economic and cultural meaning associated with rituals. Rituals play a vital role on people's socio-cultural and economic life of the community. People perform rituals in a particular place. The selection of that particular place is culturally conditioned and its meanings subjectively understood by the community. I have used local people's perspective, which helped me understand the meaning and function of rituals in their own socio-cultural context.

The main theme of this article is to discuss about how a ritual place is associated with ancestor and agriculture. I have focused on mostly to those rituals and farm and family shrines which are associated with agriculture. This article tries to demonstrate the relationships among the landscape, ritual and the process of agriculture development with some specific questions such as: 1) why that particular ritual is performed?,2) where that

Mr. Man Bahadur Khattri is an Anthropologist and has been associated with the Central Department of Sociology/Anthropology, University Campus, T. U., Kirtipur in a Capacity of Part-time Lecturer. particular ritual is performed?, and 3) why a particular space/place is chosen in order to perform that particular ritual?

In order to study ritual landscape I have focused on the Magar ethnic group of Argal VDC. I argue that ritual landscape plays a strong and important role, on the explanation of the relationship among landscape, rituals, and agricultural activities of the Magars of Argal. The concept of landscape has been used in anthropology from the beginning of the history of anthropology, however for different purposes and contexts.

Ritual landscape is a cultural phenomena, therefore throughout the world it is a construct of human beings, either through human ascription of mythological creation or through physical actions by the human themselves (Ucko 1994: xviii). Ritual landscape also called sacred landscape is also manifestations of a cosmology of local people with a distinctive array of mythical, religious, or spiritual beings or essences, which finally conceptualize and classify (i. e. bring order to, and make sense of ) the natural world (Saunders 1994:172). In Nepal, the rivers, lakes, ponds, water springs, and the Himalayas (mountains) are considered to be sacred. Wherever one goes it is easy to see a lot of rituals being performed publicly on the bank of rivers, streams, beside the water holes, lakes, ponds, on the hill forts, the top of the hills, etc. Therefore, it is difficult to separate a particular landscape from sacred to profane. Sometime Argali people consider all the geographical features or the universe as sacred phenomena, however they have special considerations for special features of the natural landscape for ritual purposes. David Holmberg has made a remark in the following way on the ritual performance in Nepal which is similar with the ritual landscape in Argal:

"Throughout Himalayan Nepal one finds an abundant array of ritual expressions reflecting multiple Hindu, Buddhist, and indigenous forms. Lamas, Brahmans, shamans, sacrificers, monks, nuns, tantrics, ascetic medicants, and other ritualists practice in innumerable temples, houses, fields, and forests, at crude and elaborate altars, at all social gatherings, at remote peaks and high lakes, in river valleys, along trails, and in bazaars" (Holmberg 1989: xi). 
The word landscape was originally coined in the emergent capitalist world of Western Europe by aesthetes, antiquarians and landed gentry-all men (Bender 1993:1-2). More accurately it was re-coined. There was an earlier Anglo-Saxon usage of the word corresponding to the German word landschaftmeaning a sheaf, a patch of cultivated ground, something small scale that corresponded to a peasant's perception, a mere fragment of a feudal estate, an inset in a Breugel landscape. This usage had gone out of vogue by the eleventh century, replaced by word that corresponded to the larger political spaces of those with power-territories, pays, domain. And then in the seventeenth and eighteenth centuries it reemerge, tightly tied to a particular 'way of seeing', a particular experience, whether in pictures, extolling nature or landscaping an estate Jackson 1985: quoted in Bender 1993:2). Similarly, the word 'landscape' was introduced into English as a painter's technical term in the seventeenth century (Cooney 1994:32). Moreover, in contemporary western societies, it involves only the surface of the land; in other parts of the world, or in pre-modern Europe, what lies above the surface, or below, may be as or more important (Bender, 1993:1-2).

In modern usage, the words "landscape", "nature" and "scenery" share a common core of meaning. Scenery and landscape, from which the seeing occurs are often used interchangeably and both imply nature (Tuan 1974: 132, Bender, 1993, Cooney, 1994, Olwing, 1993: 309). This was a perspective by which landscape was recognized as views and vistas.

In the case of 'landscape', there is no agreement, even among scientific users of the word, whether it refers to 'the landforms of a region in the aggregate' or 'a portion of area that the eye can comprehend in a single view, vista, prospect (Olwig, 1993: 307). Knowledge of a place stems from human experiences, feeling, thought and cosmology (Tilley, 1994:15). Thus the "nature" independent has only been perceived through the mind "dependent" concepts. Cognition is not opposed to reality, but is wholly given over in the total social fact of dwelling serving to link place, praxis, cosmology and nature (Ibid).
Daniels and Cosgrove (1988:1) have defined landscape as 'a cultural image, a pictorial way of representing, structuring or symbolizing surroundings'. Thus landscape is created by people-through their experience and engagement with the world around them (Ibid), which is an entirely subjective concept. Therefore, meaning of landscape is more important for the people who are actually occupying it, their views and understanding upon landscape are conditioned by their cultural behaviors.

Thus, landscape is the entire surface over which people move and within which they congregate. Thus a person's perception or mental map of a place is what underpins his/her actions rather than the objective reality of that place, so the nature is totally socialized. It is a symbolic form, a series of signs relating to the ancestral past on which people draw in day to day experience and through which they live (Cooney 1994, Tilley 1994).

People try to dichotomize the whole landscape from a sacred and a profane or ritual and a no-ritual perspective. The concept of sacred implies restrictions and prohibitions on human behavior. Thus, if something is sacred then certain rules must be observed in relation to it; such rules ultimately turn into ritual (Hubert, 1994: 11-14). What makes things become sacred or to be used for ritual activities? The English word 'sacredness' is derived from Latin, and is defined as restriction through pertaining to the gods. The sacred/ritual landscape is often looked upon as composed of thought, perception and attitude, towards a geographical area with a distinctive array of mythical religious or spiritual beings or essences. The profane landscape results from geological processes and on occasions, humans and possibly animals, activities (Saunders, 1994:172). Similarly, a sacred space is demarcated with specially produced religious objects that sanctified human ordering of life and environment, and gave meaning to that activity (Ovsyannikov \& Terebikhin 1994:44). The secular landscape is defined as one concerned with everyday life - home, field and farm - while the sacred would be identifiable as containing special places, for example sites for ceremonial ritual and tombs (Cooney 1994: 33). 
Mircea Eliade (1957) has argued that it is impossible to overemphasize the paradox represented by every quality of sacredness, even the most elementary. By manifesting the sacred, any object becomes something else, yet it continues to remain itself, for it continues to participate in its surrounding cosmic milieu. A sacred stone remains a stone; apparently (or, more precisely, from the profane point of view) nothing distinguishes it from all other stones. But for those to whom a stone reveals itself as sacred, its immediate reality is transmuted into a supernatural reality. In other words, for those who have a religious experience all nature is capable of revealing itself as cosmic sacrality. The cosmos in its entirety can become sacred (Eliade, 1957: 12).This may further help to perform more elaborate rituals in such sacred places or sacred objects. Some special locations are imbued with benevolent sacred qualities which assist people in having good health, good luck and good energy. Other localities or the same localities are imbued with malevolent forces capable of aiding in injurious acts, infertility of animals, illness in the family etc. (Theodoratus \& LaPena, 1994: 22).

The sacred landscape is associated with their particular economic and cultural activity. There is a heavy influence of religious tradition as well. The ritual leaders have the leading role to establish the sacred landscape. The ritual landscape of Argali Magars is influenced with the indigenous religious faith and practice as well as the influence of the Hinduism. The Hindu religion practitioner like Bahun and other group are their neighbors. Hinduism is the state religion and has played dominant role in the village. Slowly and gradually the ritual landscape has become a mixture of two religious traditions and faith therefore it becomes more complex to understand. The Indigenous ritual landscape which is build in Argal is more associated with agricultural development processes which is directly observable in relation to agricultural fertility.

\subsection{The People}

The Magars are the most dominant ethnic group of Argal VDC Baglung district which constitutes $49.23 \%$ of the total population (Khattri 1995). In the context of ethnic group and their variation, especially in the case of Magars of Nepal I am trying to be specific, because I am aware of the variation of the Magars in Nepal. Sometimes the variation can be observed even in different dialects of their language. In this sense I accept some cultural variations even within an ethnic group, however such variations are not significant to the local people in relation to ethnic identity. I assume some socio-cultural variations are due to geographical location as well as the degree of the interaction with the other dominant ethnic groups who have been settled down as neighbors. Similarly, there is a challenging problem to generalize the finding of a community to an entire ethnic group especially in relation to immediate ancestors. In this article I would like to refer them as charthare ${ }^{2}$ and other pasıw a Magars settled in Argal for a long time.

The Chetties, Brahman, Blacksmiths, Tailors are the neighboring ethnic groups of Argali Magars. Each particular ethnic group or caste group identify themselves as a distinct ethnic group in relation to their social structure, kinship system, cultural values, ritual practices and acceptance of particular food items and burial practices. The Argeli Magars called pasuwa to their neighbors who came later in Argal and settled down. The Magar people came Argal and settled down from the time unknown. When they came to Argal they were hunting small games and practicing slash and burn cultivation as their main occupation for their survival. Their earliest economic life can be observed from their ritual practices, which are performed at present as the remembrance of their ancestor's activities. They probably brought millet, maize, wheat and barley as their main crop during their arrival. This is also indicates because of its uses in ritual context and elaborate ritual with some restriction before plantation and harvesting the crop. The restriction and elaborate

2 According to the elderly people charthare Argali Magars were the first settlers in Argal. There are four sub-groups among them, which includes Osasa, Nausa, Pulisa and Pun. In relation to cultural practices these Margar had dominent role in the Village. The other sub-group of Magars of Argal are Naisa, Roka (Sinjali and Ramjali) and Thapa. These were later settlers in Argal and called them pasuwa. 
use of particular types of grain is developed in order to pay regards to their ancestors rather than their other religious idea. They regard to the ancestors and the religious ideas might be interconnected.

The Magars of Nepal have been regarded as one of the indigenous ethnic groups who have accepted the Hindu value system first because of their early contact with the Hindu groups. Although many sub-groups of the Magars have lost their language and have adopted some Hindu ritual traditions in the process, they have not been totally absorbed into Hinduism (Sharma, 1977:294). From religious point of view the Magar community of Argal practice indigenous religious faith which does not fit actually with Hinduism as well as with Buddhism. Neither a shaman nor a Bahun priest is employed during the rite of transition, they ask their sister's son as the priest. The sister's son is assisted by the elderly people who are well experienced with their traditional ritual practices, but they do not have any sacred text to perform their rituals. A shaman is consulted when someone in the family get sick, and or if a shaman also know to perform other rituals but he is not recognized as the ritual leader of the community (Khattri, 1995 and 1999).

\subsection{The Study Area}

Argal VDC lies in a hilly area between 1420-300 meter above the sea level (masl). There are several hill tops with thick forest, which is the source of fodder, timber, and energy for the local people. People have been protecting this forest for a long time as the community owned. The main settlement and cultivated land lies under the hill tops and the forest. This is the land where people live, with their cattle and cultivate their rain fed land. The local people grow two seasonal crops. During the summer they grow maize, millet, soyabean, but in the high altitude people do not grow millet. During the winter people basically grow wheat, barley, naked barley, pea as the major crops. They also grow radish which is used as vegetable for their own consumption as well as to exchange with their fictive kin relatives.
The surrounding landscape looks like honey cakes on opposite side with very steep hills. It is hard to imagine, from one particular corner of the village, that there is next village beside this. Therefore, people living beside river bank have difficulties to see more landmass, but those who live in much higher area, and who climb on the top of the hill could observe people's activities in the village as well as panoramic view of the Himalayas and gigantic view of the forestrious hills.

The most lowland area of Argal VDC is also very steep, where most of the people have difficulties to take their livestock. Many people take their bullock in the field to plough with great risk. However Angakhet and Ragdam areas are relatively flat and people settled there. The low land is cultivated to grow rice. The rice field is fed by mostly temporary irrigation built by people with their own individual initiation. In this land people grow rice during the summer and leave fallow during the winter. People have started to cultivate potatoes during winter for the last ten years. The fertility of these land is maintained by leaving land fallow during the winter, irrigation and by composting during rice plantation. On the one hand this land is not that important, because the majority of the people lack this type of land, on the other hand, this small amount of land owned by a few number of people is important to the people, because this land supplies rice, a prestigious as well as ritual items for majority of the people in Argal. Even today people think that the rice bought from market is not pure ritually to offer to the gods and goddesses. The majority of the people owns land in the middle range where major settlement lies. This land is more demanding because of its fertility, slope and climate. Most of the people own cultivated land around the settlement area. This land was occupied first by charthare, Magar of Argal, later other ethnic groups like Blacksmiths, Tailors, Chettris, Bahuns, and the other sub-groups of Magars who entered from different areas of Bihunkot and Galkot into their settlement areas as pasuwa. The pasuwa people agreed upon the conditions of the indigenous Magar people. The agreement was if they do not follow their local customs, they should leave the area, which made the area to some extent a culturally homogeneous. 


\subsection{Structures of Landscape and Agricultural Processes}

People's activities produce material objects and clues of their activities in the natural landscape. Crop cultivation, animal husbandry and settlement pattern are the major cultural processes. These cultural processes are also associated with creating a sacred landscape. This is evident in the case of Argal. Crop cultivation and animal husbandry are combined practices in Argal. Sherratt (1990) suggests that agriculture requires the continuing commitment to a particular place. This is associated with the territorial consciousness of the people, which is also the result of the shortage and competition for land. Argali Magars express the consciousness of the territoriality during the ancestral ritual through two ritual actions. First, they invoke their ancestral deities and the spirits living at different places in the surroundings. Second, they mention the geographical boundaries of their ancestral or communal land and important natural resources which were mostly used by their ancestors and are valuable even for the living people today during the ritual. The territorial consciousness is also associated with the permanence of the settlement. The territorial consciousness is even expressed in the written documents during the conflict on land with their neighboring communities. These events are all associated with the process of agriculture development, ancestral cults and ritual landscape of Argal.

In Argal, sacred or ritual sites are perceived as having two fundamental qualities, i. e. benevolent and malevolent. People everywhere are always concerned about their comfortable life at present and in the future. Thus, activities towards such sacred sites might be more devotional. Nevertheless, such devotional expressions, as the recognition of a place as sacred can be made permanent by monument building, for instance temples, or miniature sanctuaries. The introduction of a monument into the 'natural' environment can signify that the human institutions that created the monument are taking on the permanence of nature: architecture and nature ideally united to be one, as exemplified in the use of nature's resources in the monument (Cooney 1994: 35). In the following sections, I will present the structure of sacred places that are associated with cultivation, settlement and animal husbandry.

\subsection{Settlement VS Non-settlement Area}

There are some limitations for people which do not allow to act according to their own interests or desire only. Those limitations are included geo-physical condition and natural rescues for their niche. In order to adapt in the local environment, Argali people have rationalized towards selecting a settlement area. The selection of a settlement site includes: an access track for human beings and domestic animals, the safer land from landslide during the monsoon season and some sources of drinking water. Besides these rationalization, the settlement area has been limited mostly in and around area where dry land cultivation is mostly available. The Argali people have not built a house for permanent residence close to the wet cultivated/irrigated land. On the one hand irrigated land is very limited and very narrow valley, and on the other hand only few people own the irrigated land. The wet cultivated land is found in lower altitude between 1600-1750 masl along the bank of Puwadhune Khola and Tara Khola rivers. In these area flooding occurs frequently during the monsoon. People do fear of flood and have not settled in those areas.

Because these valleys are very narrow and rocky, therefore most of places have difficult access for domestic animals. Most of the people own the dry cultivated land, therefore, it is comfortable for them to build a house and cattleshed near their land. Except for the main clustered village, it is possible to trace the land and their house because they are very closely settled. In Argal the main settlement lies in the middle of the dry cultivated area. Most of the settlements are located around the dry cultivated land. Ritual places are found in and around the settlement area. Therefore, one finds more ritual shrines around the settlements than non-settlements area.

\subsection{Cultivated VS Uncultivated Land}

Most of the people's activities on the land are associated with the cultivation. The agricultural activities are also 
associated with ritual performance.The surroundings of Argal VDC can be divided into two categories: cultivated and uncultivated land. The cultivated land is cultured than uncultivated. Therefore, the number of rituals activities are found to be performed more on cultivated land than uncultivated land. Basically the family shrines are placed on cultivated land. Since those shrines are associated with the fertility of the crops, livestocks and members of family. Therefore, almost every family has at least one shrine in their field, if they do not have a shrine in their own field, they join to their neighbor's shrine for ritual worshipping to protect their family members, livestocks and crops from natural calamities and diseases. The communal shrines are located on uncultivated and mostly public areas. Compare to family shrines, community shrines are few but larger in size and they are regarded as more powerful. The communal deities protect all the member of community, domestic animals, wild flora and fauna of the village from natural calamities and diseases. Having a family shrine in a private land does not bring any social status in the community. But building a monument has social economic power in the community. Those families who own a family shrine has to keep his house and farm away from being dirty. This cleanliness provides social and cultural power to the family in the community. Argali people believe that the spirit which reside at that particular place gets angry and becomes troublesome for the family if their abode becomes dirty. Therefore, it is always important for them to be aware with their activities in the field and in the house. Such ritual places restrict people's attitude and behavior, but also builds social interaction with his neighboring family as well as among their consaguinial and affinal relatives.

\subsection{Wet VS Dry Cultivation}

Wet cultivation and dry cultivation are also associated with the cultural as well as social factors. However, my concern in this article is to see about how these two factors are linked in relation to ritual behavior of Argali people. In Argal cultivated land is divided into two categories a) bari (dry cultivation) and b) khet, (wet cultivation). Ritual activities are more often performed in dry cultivation areas than in wet cultivation areas. The dry cultivated land has a longer history of cultivation, similarly people have much closer interaction with it and it is the land in which people depend more for their survival than on wet cultivated land. Wet cultivation started a few decades ago in Argal. These areas lies far from main settlement areas. Therefore, the ritual shrines are found more often on the dry cultivated land than on wet cultivated land.

\subsection{Higher VS Lower Altitude Cultivation}

The location of the cultivated land is associated with the ritual places in Argal. Dry cultivated land consists of most marginal upland and semi-marginal land around the village. This land is located in a higher altitude. The wet cultivated land is located in much lower altitude (around 1600-1750 masl). The higher altitude cultivation depends more upon natural climatic conditions especially rain. This fact might have played a crucial role for more ritual activities and for creating believes in the natural or spiritual power. Because most of the natural phenomena like flood, draught, hail stone are considered to be the happening of the wish of the super natural power, such activities are expressed through building shrines and performing rituals as a symbol for invocation to the spiritual power in higher altitude and dry cultivated land.

\subsection{Long VS Short Human Interaction with Nature}

The Argali Magars have been exploring the spiritual quality of land through interaction with nature in the process of crop cultivation and animal husbandry After a long interaction with the nature when sacred place is identified then a shrine is established to communicate with the spirit as well as to indicate a ritual place. In the history of agricultural practices dry cultivation started first with subsistence economy and later wet cultivation and specialized commercial farming. Therefore, the dry land cultivation has a longer history of cultivation and it has more ritual places than the wet cultivated land in Argal. The wet land cultivation does not depend its fertility on nature as does dry cultivation. Thus, the risk with the natural calamities is less 
and the chances of food security is higher, which is very important factor in subsistence based farm economy. The process of establishing shrines comes with the interaction between local people and nature or the spiritual beings.

\subsection{Public VS Private Uncultivated land}

For the ritual performance, it was felt important to look at the land ownership. In Argal the land ownership also affects the process of constructing ritual landscape. The location of shrine and participation of the people during the rituals are also significant when they wanted to build a monument. In Argal, the uncultivated land is divided into two categories: a) ban (public forest owned by the local communities) b) kharbari ( private forest owned by individual mainly used for fodder collection). The public forest is used more for ritual activities than the private forest. In Argal, some special places such as spring of drinking water, forest, cemetery, river and streams are public. These are the places which are possible areas where spiritual places are created and owned by all members of the community. High esteemed gods and goddesses, and the ancestral monuments are also located in public land than the individually owned land. The ritual is performed by participating on the community level. In Argal forest means public land. In such a public places high esteem gods and goddesses have been settled down. In Argal, such ritual shrines are Mai Than, Chaurasi Mai, Baraha, Siddha, Deurali, Bhume, Deuti and Jimadhani.

\subsection{Crop Cycles and Ritual Activities}

Crop seasons and some ritual activities are interwoven in Argal. The Magars of Argal produce only two seasonal crops i.e. winter and summer crops. People generally called hiude kheti (bali) for winter crop and barkhe kheti (bali) for summer crops. The hiude kheti includes wheat, barley, naked barley, pea and mustard. Pea is cultivated as mixed cropped with any of the major crop like wheat, barley, naked barley. The barkhe Kheti includes, maize, millet, paddy, soybeans, amaranths, hemp, potatoes. Maize millet are the major crops during the summer season. Vegetables are mostly grown during the summer seasons. For winter crops chaite pooja rituals are performed only one time in March just before the harvest. This ritual is performed in order to protect their harvest from natural calamities like hailstone and over rain. The people of the area are not allowed to work in their field on that particular day. The summer crop cycle starts from the end of April and last until end of September. For summer crops, people perform rituals at least two times. At first ritual is performed at the beginning of sowing maize and millet and before harvesting. The crops cycle starts with the ritual called khiyaro pooja, an auspicious day for starting sowing maize in the field. Similarly that particular day people should not work on the field. In the case of millet plantation jimadhani pooja is performed just before transplantation of millet, on that day, people are not allowed to work. For the millet and paddy they perform special ritual before weeding called harelo.

\subsection{Conclusions}

Ritual landscape is a cultural phenomena. The meaning of landscape lies on culture of a particular group of people, which signify their life circumstances and affects their ways of life. Still a confusion exists whether landscape is an array of geographical or geological features per se, or a particular culture which is deeply rooted by the cosmology of the local people. In fact, the ascription of significance to a specific configuration of geographical features is not a self-evident fact conferred by natural processes, but rather a cultural appraisal (Saunders, 1994:172). In the case of Argal, the most sacred sites are natural features. These features are springs, trees or rocks. The ritual landscape is created by the experience of the local people. In Argal ritual, landscape is not in the textual tradition, but people have constructed the ritual landscape on the ground with indigenous and Hindu religious tradition and faith. Some of the ritual sites are created on the basis of scriptural notion of cosmic space. Open air village shrines are mostly associated with farm but not with Hindu textual image. The farm and family shrines are mostly associated with the fertility of crops, livestocks and family members. The rituals are performed to avoid natural calamities such as famine and epidemics. Therefore, development of rituals and the local ritual landscape is 
associated with the dependence of local community on agriculture, to pay regards for their ancestors who made land for cultivation and avoid risk of famine and epidemics. At the same time the increased dependence on cultivation stimulates increased concern for the fertility of the crops (Haaland and Haaland, 1995:115). Similarly, in archaeological investigation, sacred sites have frequently been found around the same time as the introduction of agriculture (Scarre, 1996:591). The natural environments are culturally incorporated into the religious world of local communities. The local natural landscape is used to create ritual landscape. The ritual landscape is interrelated with the settled and cultivated lands, crop cycles and rituals activities of local people of Argal. Ritual activities of the local people are not rigid. Ritual activities of the people also change according to religious and socio- economics environment of a people in a particular area.

\section{REFERENCES}

Barth, F., 1969. "Introduction". In Ethnic Groups and Boundaries: The Social Organization of Culture Difference.Barth, F. (ed.) Oslo: Universitetsforlaget.

Bender, B., 1993. "Introduction: Landscape-Meaning and Action" In Landscape Politics and Perspectives. B. Bender (ed). Oxford: Oxford Berg.

Cooney, G. G., 1994. "Sacred and Secular Neolithic Landscape in Ireland". In Sacred Sites, Sacred Places. David L. Carmichael, Jane Hubert, Brian Reeves and Audhild Schanche (eds.). London: One World Archaeology

Cosgrove, D., 1993. "Landscape and Myths, Gods and Humans". In Landscape, Politics and Perspectives. B. Bender (ed). Oxford: Oxford Berg.

Daniels, S. \& Cosgrove, 1988. "Introduction: Iconography and Landscape". In The Iconography of Landscape: Essays on the Symbolic Representation, Design and Use of the Past Environments. Denis Cosgrove and Stephen Daniels (eds.). Cambridge: Cambridge University Press.

Gurung, O., 1996. Customary Systems of Natural Resource Management Among Tarami Magars of Western Nepal. A Ph. D. Thesis Submitted to Cornell University, Ithaca, New York.
Haaland, H. \& R. Haaland,1995. Who Speaks the Goddess's Language? :Imagination and Method in Archaeological Research. Norwegian Archaeological Review Vol 28, No. 2

Hirsch, E., 1995. "Introduction: Landscape: Between Place and Space" In Anthropology of Landscape, Perspectives on Place and Space Eric Hirsch and Michael O' Hanlon (eds). Oxford Clarendon Press.

Hitchcock, J.,1966. The Magars of Banyan Hill. Holt Rinehart and Winston, Inc.

Holmberg, D., 1989. Order in Paradox: Myth. Ritual and Exchange Among Nepal's Tamang. Delhi: Motilal Banarsidass Publishers Pvt. Ltd.

Hubert, H.\& Mauss, M.,1964. Sacrifice: Its Nature and Function. (Translated by W. D. Halls) Chicago: The University of Chicago Press.

Humbert, J.,1994. "Sacred belief and Belief of Sacredness". In Sacred Sites, Sacred Places David L. Carmichael, Jane Hurbert, Brian Reeves and Audhild Schanche (eds.). London: Routledge.

Khattri, M. B., 1995. Adaptive Systems of the Magars of Argal: An Ethnoecological Case Study of Argal VDC of Baglung District Nepal. A M. A. Thesis Submitted to Tribhuvan University. Kathmandu.

Khattri, M.B., 1999. Sacrificial Places: An Ethnoarchaeological Study of the Ritual Landscape From Argal VDC, Western Nepal. A M. Phil. Thesis in Archaeology Department of Achaeology University of Bergen, Norway.

Lahiri, N., 1996. "Archaeological Landscapes and Textual Images: A study of the Sacred Geography of Mediaval Ballabgarh". In World Archaeology: Sacred Geography. Richard Bradley (ed.) Vol. 28 No. 2 Oct. London: Routledge.

Olwing, K., 1993. "Sexual Cosmology: Nation and Landscape at the Conceptual Interstics of Nature and Culture".In Landscape Politics and Perspectives. B. Bender(ed.). Oxford: Oxford Berg.

Ovsyannikov, O. V. \& Terebikhin, M. N., $1994 . \quad$ "Sacred Place in Artic Regions". In Sacred Sites, Sacred Places David L. Carmichael, Jane Hurbert, Brian Reeves and Audhild Schanche (eds.). London: Routledge.

Saunders, N. J., 1994. "At the Mouth of Obsidian Cave: Deity and Place in Aztec Religion". In Sacred Sites, Sacred Places David L. Carmichael, Jane Hurbert, Brian Reeves and Audhild Schanche (eds.). London: Routledge.

Scarre, C, 1996. "Religion". In The Oxford Companion to Archaeology. B. M. Fagan (ed) New York: Oxford University Press. 
Sharma, P. R., 1977. "Caste, Social Mobility and Sanskrititization: A study of Nepal's Old Legal Code". In Kailash Vol. 4 No. 5 (pp. 277. 300).

Sherratt, A., 1990, "The genesis of Megaliths: Monumentality, Ethnicity and Social Complexity in Neolithic north-west Europe". In World Archaeology Vol. 22 No. 2 Monuments and Monumental London: Routledge

Slusser, M. S. 1982., Nepal Mandala: A Cultural Study of the Kathmandu Valley. Volume 1:Text. Princeton, New Jersey: Princeton University Press.

Tilly, C. 1994., A Phenomenology of Landscape: Places, Paths and Monuments . Oxford: Berg

Tuan, Yi-Fu., 1974. Topophilia: A study of Environmental Perception, Attitudes and Values. Englewood Cliffs. NJ: Prentice-Hall.

Turner, V., 1967. The Forest of Symbols: Aspects of Ndembu Ritual. Ithaca: Cornell University Press.

Ucko, P. J. "Foreword". In Sacred Sites, Sacred Places. David L. Carmichael, Jane Hurbert, Brian Reeves and Audhild Schanche (eds.). London: Routledge.

\section{DEVELOPMENT OF WATER SUPPLY AND SANITATION FACILITY IN THE RURAL AREAS OF NEPAL: AN OVERVIEW}

Jiba Nath Prasain*

\subsection{Introduction}

Safe drinking water is the basic necessity for people. Traditionally as well as culturally, Nepali people believe that flowing water is considered "pure" and "safe" for drinking and domestic purposes. Water is a multifaceted symbol in Hinduism. It is regarded as one of the panchatatawa, i.e., five primeval elements of the universe along with the earth, fire, air, and ether...water was sacred precisely because it had the potential to wash away the sin. Just as water dissolves away dirt and mud, so too does it dissolve sin. Water was regarded as papamochana, or that which frees one from sin and impurity. A person was regarded as being clean after a ritual bath, or snana. While the symbols of water as a primal matter, an instrument of purification and expiation, a unifying force and a vivifying element can all be found in Hinduism, in most of the dharmashastras, or Hindu religious texts, the symbolism of water as an instrument of purification and expiation, is pre-eminent (Sharma, 2001:37-38). As water is purifier element, women take bath for purification after delivering baby, during the death observance ritual, people take bath to purify, cleaning sins, to gain religious merits, or to perform any sorts of religious activity, taking bath is most essential part of Hindu rituals. Rig-

* J. N. Prasain is an anthropologist by discipline and worked as a free-lance development consultant in bilateral agencies Nepal and UN agencies outside Nepal. 